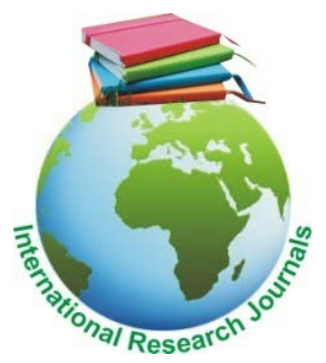

Review Article

Journal of Research in Environmental Science and Toxicology Vol. 7(1) pp. 3-9 August, 2018

DOI: http:/dx.doi.org/10.14303/jrest.2018.012

Available online http://www.interesjournals.org/JREST

Copyright @2018 International Research Journals

\title{
Communal solid waste problems in northern part of Nigeria: proposed waste management, regulatory and knowledge resolution.
}

\author{
Igibah C Ehizemhen*, Sadiq A Abubakar \\ Department of Civil Engineering, University of Abuja, F.C.T Abuja, Nigeria. igibahchrist1@gmail.com
}

\begin{abstract}
The paper attempts frequent challenges regarding civic waste administration in Northern Zone of Nigeria. It offers conjectural knowledge management techniques for confronting Northern Zone metropolitan waste difficulties. Scheme and knowledge administration systems are essential for instilling attitude correction towards waste management enrichment. Consumers, individuals and families ineffective waste management as well waste management corporations could be attributed to scanty information on waste management gain, scarcity of manufacturers' participation in waste supervision and dispossessed government rules operation.
\end{abstract}

Keywords: Communal waste administration, Environment, knowledge management, Northern, Nigeria

\section{INTRODUCTION}

Nigeria is situated in Western Africa, borders in the West by Benin Republic, Chad as well as Cameroon in the East and Niger in the north with a coastline of approximately 854 $\mathrm{km}$. It has two major rivers: Niger and Benue, these dual rivers congregate and empty into the world's biggest river delta. Nigeria is an unindustrialized country, with a land area of $909,890 \mathrm{~km}^{2}$ while its northern part has 728,113 $\mathrm{km}^{2}$, a population of about 141 million with growth rate of 2.39. In Africa it is the most overcrowded country as well ninth most populous republic throughout the world. Nigeria capital is situated in the North central with populations disseminated at $48.3 \%$ municipal and $57.7 \%$ countryside with population density of one hundred and thirty nine person per square $\mathrm{km}$ with population beneath poverty line of $65 \%$ (Olmo et al., 2016). Handling waste properly is vital for constructing sustainable and habitable cities, however it a challenge for numerous developing nations and metropolises (USEPA, 2010). Operative waste management is lavish, often encompassing $20 \%-$ $50 \%$ of metropolitan resources, unified systems that are resourceful, viable, and publicly supported is necessary in operating this important municipal service (Purity et al., 2016) Factors like improved urbanization rate, illegitimate city arrangement and developments, quick population growth rate, swift development as well ingestion pattern changes, which have been unswervingly (and indirectly) connected to the mammoth waste quantity generated, ranging from decomposable to synthetic unused (Napoleon et al., 2011). In the Northern Nigeria the quick emergent waste generation degrees and waste discarding high fee, landfill space diminution besides obtaining fresh disposal sites problem thus resulting in open discarding as unresolved subjects (Nabegu, 2010). This create challenging for waste administration authorities to ascertain and create workable solutions (Aladejebi et al., 2015). Nevertheless numerous policies besides programs have been prepared to manage metropolitan solid waste, they prove ineffectual due to monetarist and human constrictions (Purity et al., 2016). Community, Packages and Product Manufacturer, Unendorsed waste sector, Community Waste Administration Bodies and Public Establishments Policymakers plays a vital role in the success of waste controlling system which gain lots of appreciation recently. For instance in Asia, environmental ethics deficiency and alertness contribute to the solid waste administration plans catastrophe (Keser et al., 2012).

This paper work put forward difficulties associated to community solid waste administration, propose theoretical knowledge administration. For profundity understanding on these subjects and resolves, the article span crosswise existing communal solid waste administration, public waste strategies as well rules, problems distressing 
public waste administration, knowledge administration problems involving communal solid waste, anticipated knowledge administration resolves and conclusion.

\section{LITERATURE REVIEW}

\section{Prevailing Waste Management Progressions and Practices in Northern Part of Nigeria}

Metropolitan waste administration is the technique of gathering, classifying, storing, transference, processing, recycling as well discarding of unused. In Northern Nigeria, debris were regularly discarded inside drainage canals, road side, accessible exposed pits in addition flowing gully water (Nabegu, 2012). There are no authorized recycling sectors in Northern Nigeria besides recycling which is an environmentally friendly penchant though not wholly implemented. Waste are reprocessed unofficially through spongers who procure unexploited valuables from populaces as well go to endorsed and proscribed dumpsites seeking for resources that than can be re-used which is progressively obvious habit in most urbanized municipalities of Northern Nigeria. Distinct to urban megalopolises, in rural area communal solid waste amount are rarer and managed each day in courtyards as animal forages or burning, composting and intermittently disposed at scrapheap locations (Amfo-Out et al., 2012).

\section{Public Solid waste Generation in Northern Part of Nigeria}

Metropolitan solid discarded generation in Northern Nigeria ranges from zero point forty four kilogram per capital per day $(0.44 \mathrm{~kg} /$ capita/day) to zero point sixty six kilogram per capital per day $(0.66 \mathrm{~kg} /$ capita /day), the discrepancy depending on socio-economic variables like location, salary level, and nutritional habits among others. Northern Nigeria reference values accessible where quotidian waste creation in 2012 of zero point fifty six kilogram per capital $(0.56 \mathrm{~kg} /$ capita $)$, having great packaging waste proportion, squat organic moisture content as well pertinent fines amount. Eleven of such configuration is in unadorned contrast with the great carbon-based waste fractions in South Nigeria, which can be expounded by greater evaporation degrees as result of diverse climatic region, dissimilar nutritional habits, along with the public practice of using desiccated leftover sustenance as animal feed. Established from literature review as well key informer interviews, everyday waste created is ranging from point three kilogram per capital $(0.3 \mathrm{~kg} /$ capita) for rural sceneries, up to point six kilogram per capita $(0.6 \mathrm{~kg} /$ capita) for municipal settings Interviews with the Waste Management Society of Nigeria (WAMASON), besides dumpsites visual assessment confirmed stumpy organic waste stuffing and great fines as well torpid (sand, shingle, ash and skeletons) in addition wrapping waste portions. Nevertheless, approximately

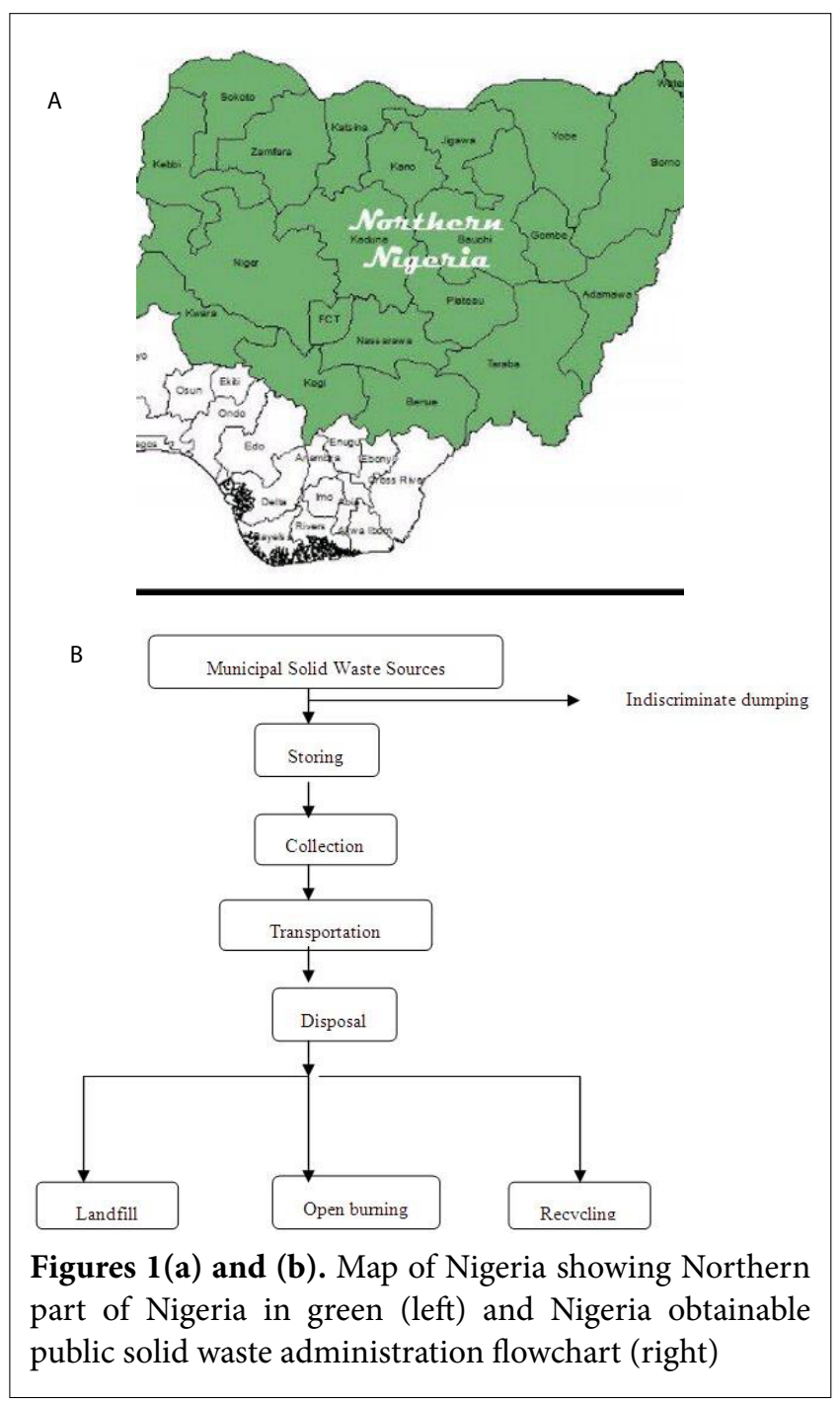

eighty percent $(80 \%)$ of created metropolitan waste has prospect of reprocess, reutilizing, or composting (Nabegu, 2010).

\section{Civic Solid Waste Source in Northern Part of Nigeria}

Northern Nigeria waste can be categorized into two namely; the first group is the light and mostly nonbiodegradable discarded, which embraces mostly bottles, plastic materials as well tins whereas the second, is the heftier predominantly biodegradable trashes that contain great proportion of dirt, food scrap, vegetables as well ash. The non-biodegradable trashes are generally found in commercial zones while the decomposable wastes are mostly connected to housing quarters. Civic solid waste can also generally grouped as: Population evolution that is Northern Nigeria covers cities like Abuja, Kano, Yola, Kaduna etcetera which is amongst the speediest growing metropolises in Nigeria, hence public wastes created in heaps on daily basis are enormous (Keser et al., 2012). Moreover, Poor town planning which normally, with the 
Table 1. Public solid waste produced for some municipalities in geopolitical regions in Nigeria

\begin{tabular}{|c|c|c|c|c|}
\hline \multirow{2}{*}{ North Geopolitical Zones } & \multirow{2}{*}{ Population } & \multirow{2}{*}{ Square Kilometer } & Distance in & \multirow{2}{*}{$\begin{array}{c}\text { Waste Generation (ton per } \\
\text { Month) }\end{array}$} \\
\hline & & & Kilometer from Abuja & \\
\hline \multicolumn{5}{|l|}{ North central } \\
\hline Benue & $4,253,641$ & 30,800 & 280 & 74,242 \\
\hline F.C.T Abuja & $1,406,239$ & 7,607 & 0 & 34,785 \\
\hline Kogi & $3,314,043$ & 27,747 & 193 & 56,780 \\
\hline Kwara & $2,365,353$ & 35,705 & 482 & 120,045 \\
\hline Niger & $3,954,772$ & 68,925 & 156 & 145,050 \\
\hline Nassarawa & $1,869,377$ & 28,735 & 180 & 243,890 \\
\hline Plateau & $3,206,531$ & 27,147 & 313 & 330,675 \\
\hline \multicolumn{5}{|l|}{ North West } \\
\hline Jigawa & $4,361,002$ & 23,287 & 512 & 127,096 \\
\hline Kaduna & $6,113,503$ & 42,481 & 186 & 312,067 \\
\hline Kano & $9,401,288$ & 20,280 & 396 & 356,676 \\
\hline Katsina & $5,801,584$ & 23,561 & 570 & 314,433 \\
\hline Kebbi & $3,256,541$ & 36,985 & 573 & 210,765 \\
\hline Sokoto & $3,702,676$ & 27,825 & 748 & 437,453 \\
\hline Zamfara & $3,278,873$ & 46,609 & 490 & 231,653 \\
\hline \multicolumn{5}{|l|}{ North East } \\
\hline Taraba & $2,294,800$ & 56,282 & 691 & 324,786 \\
\hline Borno & $4,171,104$ & 72,609 & 918 & 950,673 \\
\hline Bauchi & $4,653,066$ & 49,119 & 445 & 342,143 \\
\hline Adamawa & $3,178,950$ & 38,700 & 855 & 320,567 \\
\hline Gombe & $2,365,040$ & 17,100 & 606 & 235,345 \\
\hline Yobe & $2,321,339$ & 46,609 & 957 & 324,786 \\
\hline
\end{tabular}

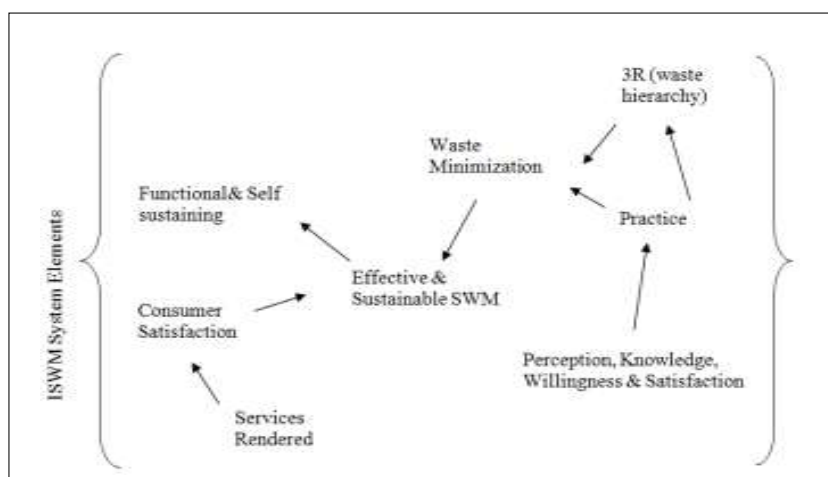

Figure 2. Research Theoretical Structure

exemption of Government Reservation Zones (GRZs), almost all parts of the Northern Nigeria towns are poorly planned. For instance, lack of access roads for cars or trucks made it problematic to relinquish or dispose solid waste dumped in such areas (Napoleon, 2011). Likewise, Urbanization practice in northern Nigeria has gone erroneous, reason that the heaps of discarded pilling up every day as result of the gigantic indifference on the people part besides their emotional loss and liable relation to the environment due to colonization (Keser et al., 2012). Additionally, failure of all three tiers government to relinquish civic solid waste causes persistent problems especially state government believe that solid waste management is traditional obligation of a local government, which resulted to coordinated jurisdiction privation with no principles or specifications established (OImo et al., 2016). Furthermore, deficient or scarce knowledge of some northern Nigeria residents on environment functions or sciences techniques has contributed to civic solid waste heaps. Huge illiteracy or ethnic as well religious proclivities rate of good proportion of the feminine populations of Northern Nigeria are not extensively educated on environmental influences of discarding solid waste comprehensively. Even though they are reprimanded on the dangers of civic solid waste like diseases they will answer "Allah ne mai kiyaye wa" meaning "GOD is the one that guards." Their socio-cultural besides religious belief is that all things either good or bad comes from Allah (GOD). More so, commercial nerve of the northern Nigeria is categorized with enormous and many marketplaces which resulted to outsized quantity of solid waste seen all over the place in the markets. Conclusively, notion of common resources ownership like opens spaces and playgrounds is "no man's land" also make mankind to pile metropolitan solid waste heaps in such zones.

Table 2. Solid waste material and percentage

\begin{tabular}{|l|c|}
\hline Material & Percentage \\
\hline Carbon-based & $17.4 \%$ \\
\hline Polythene / cellophane & $19 \%$ \\
\hline Paper & $12.9 \%$ \\
\hline Metallic & $11 \%$ \\
\hline Glass & $8.9 \%$ \\
\hline Plastics & $11.2 \%$ \\
\hline Fines (dust, ash \& sand) & $12.3 \%$ \\
\hline Other & $9.3 \%$ \\
\hline
\end{tabular}


Table 3. Waste sources with percentages

\begin{tabular}{|l|c|}
\hline Sources & Percentages \\
\hline Housing & 62.7 \\
\hline Commercial & 26.8 \\
\hline Manufacturing & 2.8 \\
\hline Institutional & 5.8 \\
\hline Others & 1.9 \\
\hline
\end{tabular}
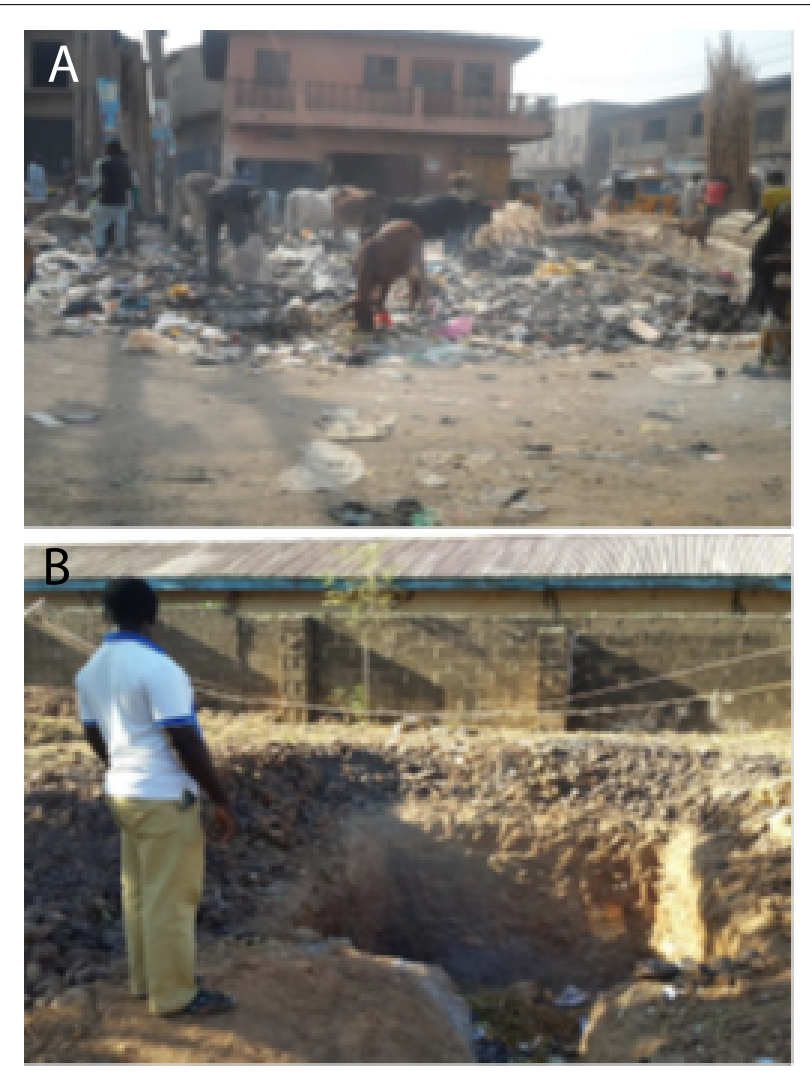

Figure 3(a) and (b). People and animal foraging near buildings at Sabon Gari Kano (left) and waste pit with no marking or fencing (right)

\section{Harmful Practices}

Waste inopportune management proliferations the vector disease transmission risk by generating breeding locations for flies and parasites as well falls incidents especially children likes falls which result in injures and fractures, wounds, and punctures. Uncluttered dumping, comprising of waste dumping in the rivers and drainage canals also injurious to human well-being as well the environment. Likewise, waste bottleneck drainage channels generate ideal breeding lands for vectors (mosquitoes) as well intensify flood danger by hampering water flow.

\section{Existing Waste Management Strategies and Rules in Nigeria}

Waste administration is amongst the vital for all there tiers of government in Nigeria. For instance Federal

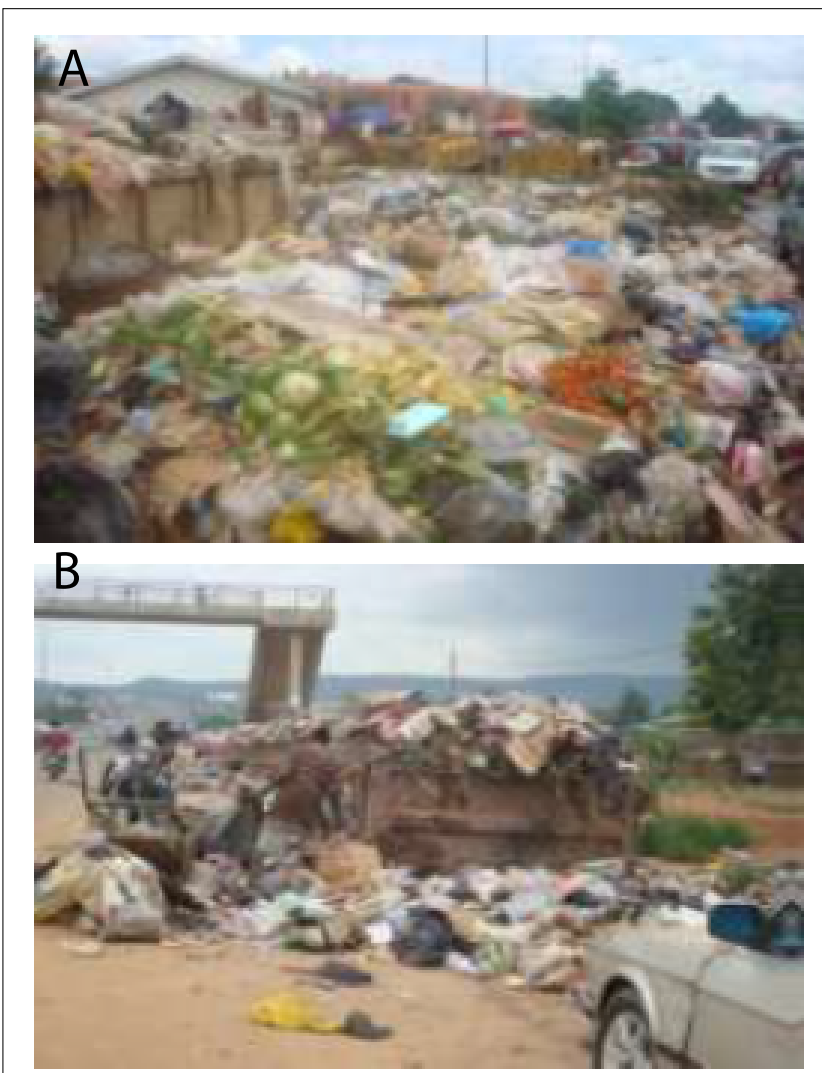

Figure 4(a) and (b). AMAC Nyanya District (left) and AMAC Federal Capital City (right)

Environmental Protection Agency (FEPA) were indorsed by The Federal Government of Nigeria on $30^{\text {th }}$ December 1988, Lagos state create Lagos State Environmental Protection Agencies (LASEPA) who is answerable to environmental protection, also Lagos State Waste Management Agencies (LAWMA) as well MEPP (the Ministry of Environment and Physical Planning). Regardless of Federal Government of Nigeria Rule Goals which embraces: Securing quality localities for all Nigerians aptness, well-being and to stimulate individual and civic involvement in environmental protection and enlargement efforts (USEPA). Other by-law are, The National Protection Administration of Solid and Harmful Wastes Directive of 1991; The Pollution Reduction in Industries and Facilities Producing Waste By-law of 1991 and The General Stratagems for Pollution Attenuation in Industries 1991 (Agwu, 2012) (Adedeji \& Ako, 2009).

\section{Solid Management Difficulties in Civic Waste Management in Northern Nigeria}

Wastes are observed as inimitable as well unusable resources instead of wealth, they are not professed as precious resources which can be reclaimed for tangible uses, material reclamation and energy recoup. Firstly, there is waste Infrastructure deficiency in the Northern Nigeria such as building or upgrading waste cataloguing 
and treatment amenities, close dumps, create or overhaul landfillsas well provide bins, dumpsters, lorries, and transfer stations. Moreover, Legal structures and institutions like projects advice on comprehensive policy measures as well coordinated establishments for the metropolitan waste management region is absent in the Northern Nigeria. Despite Nigeria is countersigner to many worldwide and district Multilateral Environmental Agreements (MEAs) for instance the Rotterdam, Basel, Bamako, Stockholm, and Bamako Conventions. Though its oil production has a well-built set of environmental rules and regulations, specifically concerning precarious waste. Furthermore, lack of financial sustainability; this can be done through the taxes and fee structures scheme and long standing planning, which help governments to improve waste price repression and recovery. Likewise, citizen engagement is poor because no supports like designing incentives and alertness schemes to stimulate waste lessening, sourceseparation as well reuse since behavior change and public involvement is crucial to efficient waste. Additionally, lack of social insertion as most developing nations depend on heavily on unofficial workers to gather, sort as well recycle fifteen to twenty percent of engendered waste. Similarly, there is no perceptible waste projects that support suppleness by decreasing waste discarding in waterways and conservation infrastructure against flooding in Northern Nigeria. Although this program is in support of conservatory gas mitigation through food forfeiture and waste lessening, organic waste alteration as well adoption of discarding technologies that incarcerate biogas and landfill gas. Convincingly, Knowledge creation strategy and exploration of apposite solutions through technical knowhow, data and analytics is lacking in Northern Nigeria.

\section{Proposed Waste Management Resolutions}

\section{Local authorities' capacity building}

The monetarist and human resources competency, as well as tools and vehicles are different from state to state. Exposed burning must be discouraged and there should be introduction of communal waste pits in all part of Northern Nigeria while the existing ones that not currently used should be obligatory for use. Waste pits must be noticeably marked and enclosed to prevent youngsters and animals falling to them, soil layer garnish should be frequently added at least once per week to avert vector breeding well there should be provision of extra defensive kit like coveralls, gloves, waders and masks on cases.

\section{Emergency employment}

This could support precise waste gathering and recycling projects by local authorities for instance the gathering of waste plastic sheets as well bags for reutilizing and the public storage containers building. Engaging in clearing of proscribed dumpsites (bizarre clean ups); drainage channels clearance from garbage and residue (flood menace lessening); routine waste collection from roads and other communal spaces.

\section{Incentive scheme}

There should be small motivation in exchange for recyclable waste like paper, plastic bottles, cardboard, tin as well aluminium containers besides hazardous waste for instance secondhand fluorescent light bulbs and batteries. Recyclables incentive can be monetarist or based on market fees for the merchandised materials; undamaged hazardous waste conversely could be exchanged with its non- discarded equivalent on a tiniest ratio of five to one meaning five utilized in exchange for one new. The companies that package recyclable items like cartons, plastic as well tins must provide comprehensive descriptive label with English languages in addition three core languages of the nation (Yoruba, Hausa as well lgbo) on the recyclables containers with certain motivations dedicated for returning of such stuffs with real containers price to be included to the items purchasing price.

\section{Fuel briquettes}

Fuel briquettes manufacturing from waste paper, cardboard as well agricultural waste is anticipated to develop virtually non obtainable value chain which is of paper recycling thereby diminish the deforestation burden through partially substituting firewood as food preparation fuel in communal kitchenettes. As well creation and retailing of fuel briquettes can possibly become a source of employment.

\section{Planning and Enactment of waste management systems}

Contemporary waste administration practices in Northern Nigeria (open discarding, burning and waste pits) and the location of menacing waste presence in some part of Northern Nigeria needs methodical place tidying as well returning them to their unique function. Transnational guidelines on mothballing should be incorporated with prevailing Nigerian legislation for safe cleaning techniques and directives on the suitable cleanup in addition remediation actions.

\section{Recycling infrastructure support}

BOSEPA aviator scheme for reprocessing plastic bags into paving blocks must be sustained through teaching of paving blocks manufacturers the method.

\section{Establishment of standard procedures for waste clearance}

Transnational humanitarian actors like UNDP, UNICEF besides demining NGOs, NEMA, the Nigerian Army and 
SEMAs have to develop Standard Operative Procedures (SOPs) for rubbish clearance.

\section{Worldwide partners}

Nigeria Government must design efficient partner program with transnational waste management bodies for instance World bank that engagement in solid waste management as well has backing from valuable conglomerates comprising funding from the Global Partnership on Output-Based Aid (GPOBA), Climate and Clean Air Coalition (CCAC), Korean Green Growth Trust Fund (KGGTF) in addition alliance on capacity building besides knowledge distribution through understanding memorandum with the ISWA (International Solid Waste Association).

\section{Knowledge management}

The public waste administration chains which encirclements of civic waste originators, wrapping companies and waste administration organizations must be waste orient knowledgably that is grasp waste as

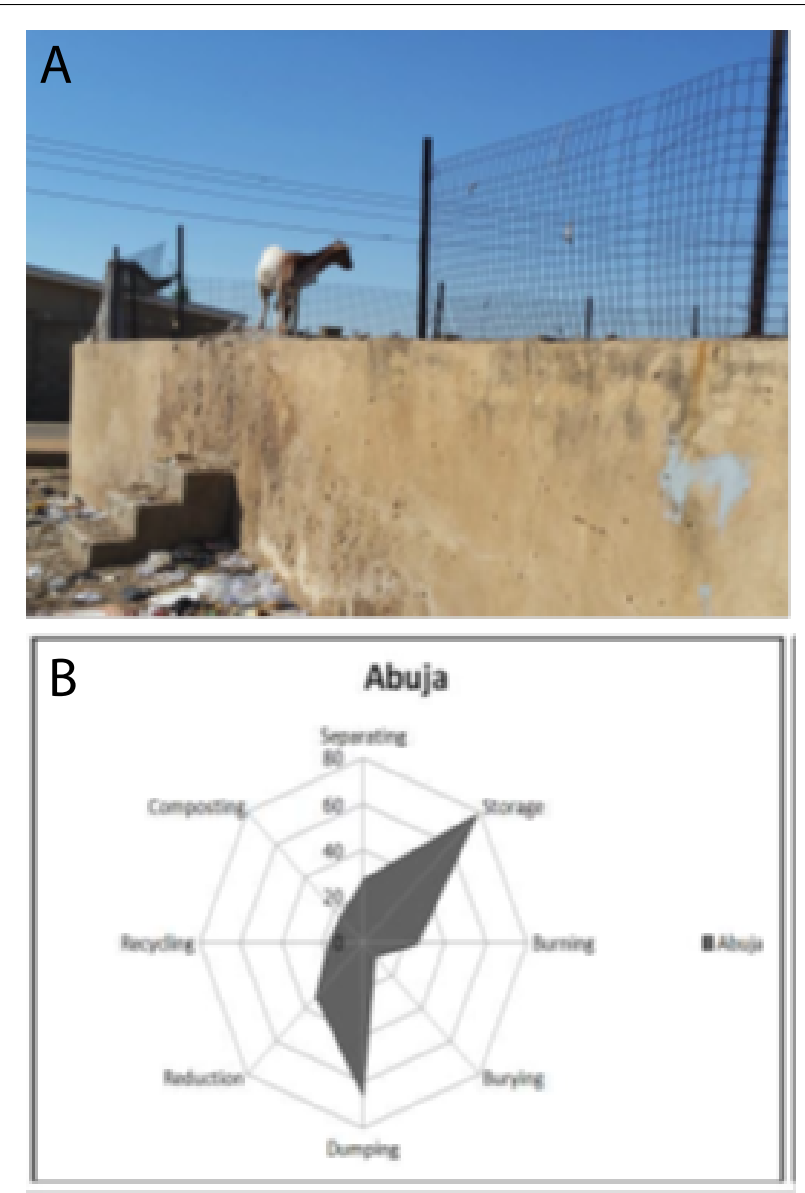

Figure 5(a) and (b). Prototype of old collection points (left) and Radial diagram showing pattern of Solid Waste Management Practices (right) cherished resource as well cognizant with health risks of unrestrained waste discarding in residential zones. The face to face announcement technique should be engaged by the civic waste administration corporations to interrelate as well familiarize with metropolitan area members on discarding conducts, categorization besides waste storage in an environmental approachable manner.

\section{CONCLUSION}

Nigeria Traditional belief is a main hindrance to wellorganized discarded management, others are waste Infrastructure deficiency, Legal structures and institutions absenteeism, lack of financial sustainability done through the taxes and fee structures scheme, poor citizen engagement as result of no supports like designing incentives and alertness schemes, lack of social insertion, no perceptible waste projects that support suppleness by decreasing waste discarding in waterways and conservation infrastructure against flooding; privation of packaging and product firms' partaking and interventions; inadequate alliance with transnational bodies besides knowledge creation strategy and exploration of apposite solutions through technical know-how.

\section{ACKNOWLEDGEMENT}

The author would like to thank the Danish Development Agency (DANIDA) for financial support via Haramaya Camel Dairy Project.

\section{REFERENCES}

Adedeji A and Ako T (2009). Towards achieving the United Nations' Millennium Development Goals: The imperative of reforming water pollution control and waste laws in Nigeria. Desalination. 248: 642-649.

Agwu O (2012). Issues and Challenges of Solid Waste Management Practices in Port-Harcourt City, Nigeria- a behavioural perspective. Am. J. Soc. Mgmt. Sci. 3(2): 83-92.

Aladejebi O, Adeyeye A and Olatunji E (2015). Assessment of Solid Waste Management in IFE North Local Government Area, Osun State, Nigeria. Int. J. Sci. Res. 5(9):1-8.

Amfo-Out R, Waife ED, AdjeiKwakwa PA and AkpahYeboah S (2012). Willingness to Pay for Solid Waste Collection in Semi-Rural Ghana: A Logit Estimation. Int. J. Multidiscip. Res. Dev. 2(7): 40-49.

Keser S, Duzgun S and Aksoy A (2012). Application of spatial and non-spatial data analysis in determination of the factors that impact municipal solid waste generation rates in turkey. Waste. Manag. 32: 359-71.

Napoleon S, Kingsley O and Joan E (2011). Mitigating the impact of solid wastes in urban centres in Nigeria. J. Hum. Ecol. 34(2):125-133. 
Nabegu B (2010). An analysis of municipal solid waste in Kano metropolis, Nigeria. J. Hum. Ecol. 31(2):111-119.

Nabegu B (2012). Using Pearson product moment correlation to explore the relationship between different categories of Municipal solid waste in Kano metropolis, North-western Nigeria. Journal of Environment and earth Sciences. 2(4): 63-67.

NBS (2009). Social statistics in Nigeria. National Bureau on Statistics Abuja.

Olmo F, Grundy M and Bjerregaard M (2016). North-
East Nigeria Waste \& Debris Assessment Final Report UNDP.

Purity NO, Anekwe R, Ifeoma and Attah EY (2016). Waste management and sustainable development in Nigeria: A study of Anambra state waste management agency. European Journal of Business and Management. 8(17): 132-144.

United State Environmental Protection Agency (USEPA) (2010). Landfill recovery and Use in Nigeria (Pre- feasibility studies of using Landfill Gas Energy (LFGE). A report prepared by Centre for People and Environment (CPE). 